\begin{tabular}{c} 
International Journal of Engineering \& Technology, 7 (2.29) (2018) 826-829 \\
International Journal of Engineering \& Technology \\
SPC \\
Website: $w$ ww. sciencepubco.com/index.php/IJET \\
Research paper \\
\hline
\end{tabular}

\title{
Evaluation of Jordanian Banks Websites Usability
}

\author{
Abeer Rafi'i Al Abdulraheem ${ }^{1 *}$, Rabab Abumalloh², Waheeb Abu-Ulbeh', \\ ${ }^{1,2}$ Computer Department, Community College, University Of Dammam \\ ${ }^{2,3}$ Faculty Of Computing, Universiti Teknologi Malaysia, 81310 UTM Johor Bahru, Malaysia \\ *Corresponding Author E-Mail: Arabdulraheem@Uod.Edu.Sa
}

\begin{abstract}
Being convinced of the importance of online banking, as a new competitive advantage that every bank around the world is rushing to gain, the following research question motivated the authors to investigate; to what extent is any bank's website is usable and beneficial to customers? This research is about evaluating Jordanian banks' websites; we have followed one approach for evaluating these websites. This approach is evaluating our sample according to the WEBUSE model developed by Chiew and Salim (2003). The results of the evaluation process have indicated that the banks websites are nearly of close quality in their functional attributes or services the bank's website offers, as well as in the user's acceptance of other features adopted in the WEBUSE index. Finally, this research concludes that the chosen sample of Jordanian banks' websites are of excellent to good quality or usability level.
\end{abstract}

Keywords: Evaluation; E-Banking; WEBUSE Model

\section{Introduction}

Banking is one of the fields that have entered the Internet strongly, which has raised the term e-banking. Most of the banks nowadays have a website as part of its entry into the e-commerce era essentials. According to Francisco Javier Miranda et al. (2006), there are two alternatives for Internet banking: the first, a bank that physically exists builds its own website as an additional channel to reach customers and deliver services to them - sort of gaining a marketing competitive advantage- and thus getting feedback from them. The second alternative, is a bank having an Internet-only presence or what is called a virtual bank. In the case of Jordanian banks; only the first alternative holds; since every bank in the sample is a bank that really exist and having a website.

According to Siam (2009), Jordan as a developing country has an advanced banking system in comparison with other countries in the region. This progress is due to the political and economic stability which Jordan enjoys for a long time, accordingly there have been great advances in the field of e-banking in Jordan since the year 2001. Since that time, most of the Jordanian banks have constructed their own websites.

According to Abu Shanab et al. (2009), most of the Jordanian banks have adopted some type of Internet usage and have launched websites to introduce services to their customers. In the year 2001, there were only two banks that have supported customer's transactions through their websites, and by the end of 2007 sixteen banks have jumped on the Internet banking wagon.

\section{Literature Review}

In the last few decades: there were great advances in the different fields of Information Technology, the Internet, and different tools for communication. It was a natural result to see that such advanc- es have great impact on all aspects of our life, medicine, industry, education, and every other field, not to forget mentioning commerce.

Merging the advances we mentioned above have led to the new era of e-commerce, which caused every enterprise to construct its own e-commerce website as a competitive advantage. According to Husain et al. (2009), e-commerce allows organizations to communicate with customers, build strong relationships with them, tell them more easily about their services and know more about them.Banks sector has also adopted the idea of e-commerce yielding into what is called e-banking in which services offered by banks to their customers can be accomplished online through the banks website.

According to Albuquerque et al.(2002), online banking is a growing part of E-Commerce which provides interactive services such as: accessing account summary information, paying bills, and accessing other banking products and services.

Online banking has been around for quite a few years, actually, it has started in the 1980s and has great advances since that time. The last decade has seen great advances in Internet banking transactions. Several pieces of legislation have also been introduced in this area.

Despite the fact that online banking has began in the 1980s, it was only in the mid of the 1990's that Internet banking have really started. What attracts customers to Internet banking is $24 / 7$ availability and ease of transactions. Studies have estimated that Internet banking still has a long way to go. Statistics released by FDIC (Federal Deposit Insurance Corporation) have shown that only $40 \%$ of the banks in the U.S. offer Internet banking facilities that worth mentioning. All others may have an online presence, but do not have enough online transactions to justify their presence on the Internet.

According to Siam(2009), Jordan as a developing country has an advanced banking system in comparison with other countries in 
the region. This progress is due to the political and economical stability which Jordan enjoys for a long time, accordingly there have been great advances in the field of e-banking in Jordan since the year 2001. Since that time, most of the Jordanian banks have constructed their own websites.

And according to Abu Shanab et al. (2009), most of the Jordanian banks have adopted some type of Internet usage and have launched websites to introduce service to their customers. In the year 2001, there were only two banks that have supported customer's transactions through their websites, and by the end of 2007 sixteen banks have jumped on the Internet banking wagon.

\section{Methodology/Materials}

The most important measure for a website quality is its usability, knowing that if a user could not get the expected results of surfing a website he will abandon that website. We will try to assess the usability of some Jordanian banks web sites. The main objective of this study is to evaluate the usability of the websites of some of the leading Jordanian banks. In our early literature review phase, available literature was searched looking for the usability evaluation techniques conducted by other researchers, guidelines and criteria that will be evaluated were also searched for. The research methodology the authors followed in this research is presented in figure1.

The tool we have used for our qualitative evaluation of the websites is a questionnaire that we have built as a web application named USET (Usability Evaluation Tool), our set of participants have used this tool to make the evaluation process easy for them. Other tools available on the web such as the online tools offered by SEO (Search Engine Optimization) websites. And online tools offered by Google, to compute the page rank of any website, and so on. Our sample consisted of seven Jordanian banks web sites, the Jordanian central bank was excluded because it falls in another domain which is the .gov domain, in addition to being a bank of no regular customers, other banks were excluded as well because they are not literally Jordanian banks, but are universal banks having branches in Jordan. Table 1 shows the names of the Jordanian banks in the chosen sample.

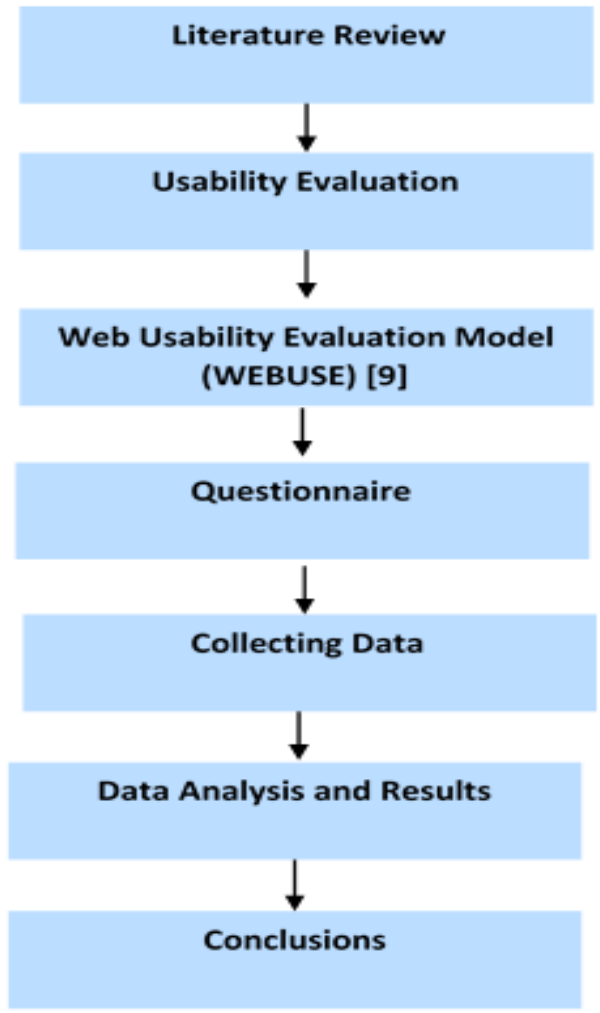

Fig. 1: Research Methodology
Table 1: The Jordanian Banks Chosen in the Sample

\begin{tabular}{|l|l|l|}
\hline $\begin{array}{l}\text { N } \\
\text { O }\end{array}$ & Bank's Name & Banks Website \\
\hline 1 & Bank of Jordan & $\underline{\text { http://www.bankofjordan.com }}$ \\
\hline 2 & Arab Bank & $\underline{\text { http://www.arabbank.jo }}$ \\
\hline 3 & Al Ahli Bank & $\underline{\text { http://www.ahli.com/ }}$ \\
\hline 4 & Cairo Amman Bank & $\underline{\text { http://www.cab.jo/ }}$ \\
\hline 5 & $\begin{array}{l}\text { Jordanian Islamic } \\
\text { Bank }\end{array}$ & $\underline{\text { http://www.jordanislamicbank.com/ }}$ \\
\hline 6 & The Housing Bank & $\underline{\text { http://www.hbtf.com/wps/portal }}$ \\
& & $\underline{\text { http://www.arabbanking.com.jo/ar/ar- }}$ \\
7 & Arab Finance Bank & $\underline{\text { index.html }}$ \\
\hline
\end{tabular}

After reviewing the available literature about usability evaluation, we have decided to evaluate our sample websites using the criteria that were discussed in Chiew and Salim(2003), Mustafa and AlZoua'bi(2008), Toit and Bothma (2009), which we think will be the most suitable method for evaluating the Jordanian banks websites sector for the following reasons:

- Chiew and Salim (2003), Mustafa and Al-Zoua'bi (2008) and Toit and Bothma (2009) focused in their studies on four common evaluation categories namely (Content, organization and readability), (Navigation and links), (User interface design), and (Performance and effectiveness).

These categories which are basically developed by Chiew and Salim (2003) after an extensive study of evaluation tools are claimed by them to be suitable for evaluating any website.

As we have mentioned above, the categories that we will focus on in our evaluation process are the categories that have been extracted from the above literature, some of these categories would intersect; which indicate clearly that those categories are overlapping.

For evaluating the criteria found in the WEBUSE model we will use a web application based tool; the USET (Usability Evaluation Tool) that we have built earlier. Since all of the criteria within this model are subjective and need to be tested empirically (i.e. by users). The empirical technique followed for evaluating the criteria found in the WEBUSE model relied on a set of 30 users who were asked to fill in the questionnaire using the USET tool we have built earlier. In the USET tool the questions appear on the top of the window, while in the bottom a full capability browser is included. The set of questions that should be answered by every evaluator will show consequently above the website that will be evaluated, the user will choose his/her answer after evaluating the criteria and then moves to the next question. The user can't go to the next website without answering all the questions related to the current website. The answers are directly saved in a database and are then exported to an excel file for further analysis. Screenshots of the USET tool are given in Figures 2 and 3.

\subsection{The questionnaire}

The categories that we included within this questionnaire include Content, Organization and Readability as well as Navigability, User interface design and Performance and Effectiveness

- Content Organization and Readability

In this category, the user will answer questions regarding his/her acceptance of the organization of the information within the interface of the website, and how easy is it for a user to find what he/she is looking for, and to what extent the user is comfortable in using the website. While it does not make sense to ask users to evaluate the readability attribute of the website, this is because too many technical issues are related, and so we decided to use the tools available on the Internet for evaluation purposes.

- $\quad$ Navigation and Links

This category allows us to assess how easily a user can know where he is within a website, which is so important for users not to have the feeling of being lost in the website. In addition to other attributes that must hold in any website, so as to be considered navigable, details are given in Table 2

- User Interface Design 
This part of the questionnaire is related to the acceptance of the aesthetic features of the website by users, details are given in Table 2

\section{- $\quad$ Performance and Effectiveness}

This part of the questionnaire is related to the subjective acceptance of the evaluators of the response time, download speed of the home page of the website as well as other features that we will assess in our questionnaire of functional categories in a quantitative manner.

\subsection{Evaluators Sample}

Our set of evaluators consists of 30 computer science teachers who work at the Jordanian MOE (Ministry of Education) schools. 15 of them were males and the rest were females with ages ranging from 25 to 45 years old. All of our participants have an equal knowledge in using a computer and the Internet.

\subsection{USET Data Analysis}

The answers of the users who have evaluated the websites using the USET tool were automatically exported to excel sheets. Every question has four possible answers (strongly agree, agree, disagree, strongly disagree and not applicable) the categories evaluated within the WEBUSE model and their corresponding criteria are in Table 2.

Table 2: The Categories Evaluated within the WEBUSE Model and Their Corresponding Criteria

\begin{tabular}{|c|c|c|}
\hline $\begin{array}{l}\mathbf{N} \\
\mathbf{0} \\
.\end{array}$ & Category & Subcategory \\
\hline \multirow[t]{6}{*}{1} & $\begin{array}{l}\text { Content, organi- } \\
\text { zation, and read- } \\
\text { ability }\end{array}$ & $\begin{array}{l}\text { This website contains most of my interest } \\
\text { material and topics and they are up-to-date. }\end{array}$ \\
\hline & & I can easily find what I want at this website. \\
\hline & & The content of this website is well organised. \\
\hline & & Reading content at this website is easy. \\
\hline & & $\begin{array}{l}\text { I am comfortable and familiar with the lan- } \\
\text { guage used. }\end{array}$ \\
\hline & & $\begin{array}{l}\text { I need not scroll left and right when reading at } \\
\text { this website. }\end{array}$ \\
\hline \multirow[t]{6}{*}{2} & $\begin{array}{l}\text { Navigation and } \\
\text { links, }\end{array}$ & I can easily know where I am at this website. \\
\hline & & $\begin{array}{l}\text { This website provides useful cues and links } \\
\text { for me to get the desired information. }\end{array}$ \\
\hline & & $\begin{array}{l}\text { It is easy to move around at this website by } \\
\text { using the links or back button of the browser. }\end{array}$ \\
\hline & & $\begin{array}{l}\text { The links at this website are well maintained } \\
\text { and updated. }\end{array}$ \\
\hline & & $\begin{array}{l}\text { The website does not open too many new } \\
\text { browser windows when I am moving around. }\end{array}$ \\
\hline & & $\begin{array}{l}\text { Placement of links or menu is standard } \\
\text { throughout the website and I can easily rec- } \\
\text { ognise them. }\end{array}$ \\
\hline \multirow[t]{6}{*}{3} & $\begin{array}{l}\text { User interface } \\
\text { design }\end{array}$ & This website's interface design is attractive. \\
\hline & & $\begin{array}{l}\text { I am comfortable with the colours used at this } \\
\text { website. }\end{array}$ \\
\hline & & This website has a Consistent Feel and Look \\
\hline & & Little Use of Advertisement \\
\hline & & This website is suitable for audience \\
\hline & & $\begin{array}{l}\text { This website contains little amount of scroll- } \\
\text { ing or blinking text }\end{array}$ \\
\hline \multirow[t]{4}{*}{4} & $\begin{array}{l}\text { Performance and } \\
\text { effectiveness }\end{array}$ & $\begin{array}{l}\text { I need not wait too long to download a file or } \\
\text { open a page. }\end{array}$ \\
\hline & & $\begin{array}{l}\text { I can easily distinguish between visited and } \\
\text { not-visited links. }\end{array}$ \\
\hline & & $\begin{array}{l}\text { This website responds to my actions as ex- } \\
\text { pected. }\end{array}$ \\
\hline & & It is efficient to use this website. \\
\hline
\end{tabular}

Answers of questions are then transformed into their corresponding merits and then a usability point for each category $\mathrm{x}$, is defined and calculated as:

$\mathrm{x}=\sum$ (Merit for each question of the category) / number of questions

The usability score of each bank is then computed as in Toit and Bothma (2009). The final usability score of each site is computed using the following equation:

Overall website score $=\sum$ Overall Scores of all Categories / Number of Categories

\section{Results and Findings}

The results of evaluating the four categories within the questionnaire are presented in Table 3 and Figure 2 and Figure 3 computing the results, the evaluators' answers were transformed to numeric values according to the merits given in Table 3

The usability score for each of the four categories for each bank's website are presented in Figure 3

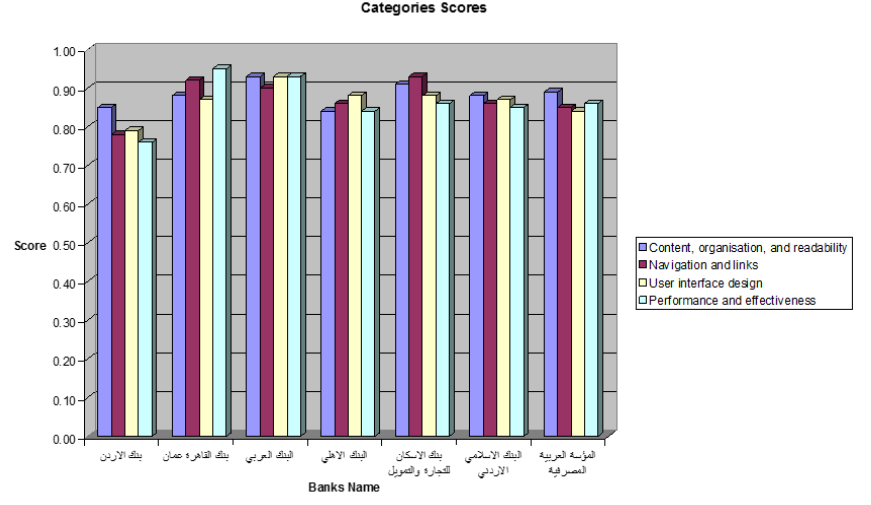

Fig. 2: Distinct Categories Scores

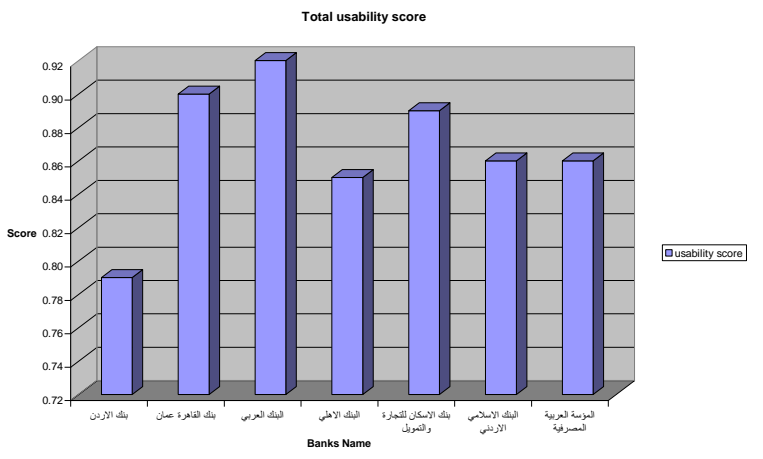

Fig. 3: Total Usability Score

Table. 5: Total Usability Score and Corresponding Usability Level

\begin{tabular}{|c|c|c|c|}
\hline 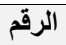 & اسم البنك & usability score & usability level \\
\hline 1 & بنك الاردن & 0.79 & Excellent \\
\hline 2 & بنك القاهرة عمان & 0.9 & Excellent \\
\hline 3 & البنك العربي & 0.92 & Excellent \\
\hline 4 & البنك الاهلي & 0.85 & Excellent \\
\hline 5 & بنك الاسكان للتجارة و التمويل & 0.89 & Excellent \\
\hline 6 & البنك الاسلامي الاردني & 0.86 & Excellent \\
\hline 7 & المؤسة العربية المصرفية & 0.86 & Excellent \\
\hline
\end{tabular}

\section{Conclusion}

This representation reveals that most usable bank's website belongs to the Arabic bank and the less usable one belongs to the bank of Jordan website. But the difference in score is not that high and they are approximately close. This study was conducted to evaluate the websites of some of the Jordanian leading banks, the evaluation process revealed that these banks' websites are of excellent to good quality, and are usable from many different per- 
spectives (i.e. the categories we evaluated in both measures). During the research phases we came up with an idea about how much is online banking adopted by bank's customers, this idea was not that bright; since we did not find people who are using online banking that easy. If we assume that our set of 30 evaluators are a random sample selected for evaluation, then the percentage of users who use online banking service is equal to 0.03 which is very low.

\section{References}

[1]. Akt Thiam Kian Chiew, Sitti Salwa Salim, (2003),"WEBUSE WEBSITE USABILITY EVALUATION TOOL", Malysians Journal of Computer Science, Vol. 16 no. 1, June 2003, PP.47-57

[2]. Francisco Javier Miranda, Rosa Cortes, Cristina Barriuso, (2006), "Quantitative Evaluation of e-Banking Web Sites: an Empirical Study of Spain Banks", The Electronic Journal Information Systems Evaluation Volume 9 Issue 2, pp 73 - 82, (2006) Available online at www.ejise.com

[3]. Ahmad Zakaria Siam, (2009), "The Effect of Banks Merger on Electronic Banking Services Competency", Journal of Social Sciences 5(1): 76-79, ISSN 1549-3652 @ 2009 Science Publications, 2009

[4]. Emad Abu-Shanab, Michael Pearson, (2009), "Internet Banking in Jordan: An Arabic Instrument Validation Process", The International Arab Journal of Information Technology, Vol. 6, No. 3, July 2009235

[5]. Ashok Darisipudi, Sushil K. Sharma, "USABILITY TESTING OF ONLINE MAGAZINE AND SUBSCRIPTION SERVICE”,

[6]. Suleiman H. Mustafa, Loai F. Al-Zoua'bi, "Usability of the Academic Websites of Jordan's Universities An Evaluation Study", Faculty of Information Technology, Yarmouk University, Irbid, JORDAN

[7]. Du Toit, M., \& Bothma, C. (2009). Evaluating the usability of an academic marketing department's website from a marketing student's perspective. International Retail and Marketing Review, 5(1), 25-37.

[8]. Hussain, O., Ahmad, F., \& Yahaya, J. (2009). Comparison of quantitative and qualitative methods of e-commerce websites evaluation. MASAUM Journal of Reviews and Surveys, 1(1), 20-26.

[9]. Albuquerque, A. B., \& Belchior, A. D. (2002). E-commerce Website quality evaluation. In Euromicro Conference, 2002. Proceedings. 28th (pp. 294-300). IEEE.

[10]. Siam, A. Z. (2009). The Eff ects of Bank Merger on Electronic Banking Services Competency. Journal of Social.

[11]. Abu-Shanab, E., \& Pearson, J. (2009). Internet banking in Jordan an Arabic instrument validation process. Int. Arab J. Inf. Technol., 6(3), 235-244. 